\title{
Molecular cloning and characterization of the human WISP-2/CCN5 gene promoter reveal its upregulation by oestrogens
}

\author{
Asmaà Fritah, Gérard Redeuilh and Michèle Sabbah \\ Institut National de la Santé et de la Recherche Médicale, U673, Hôpital Saint-Antoine, Université Pierre et Marie Curie (UPMC-Paris 6), Paris, France \\ (Requests for offprints should be addressed to M Sabbah; Email: sabbah@st-antoine.inserm.fr)
}

\begin{abstract}
Wnt-1-induced signalling pathway protein-2 (WISP-2)/ connective tissue growth factor/cysteine-rich 61/nephroblastoma overexpressed (CCN) 5 is a member of the $\mathrm{CCN}$ family of growth factors and was identified as an oestrogen- inducible gene in the MCF-7 cell line. However, the role of WISP-2/ CCN5 in breast carcinogenesis remains unclear. In this study, we examined the mechanism by which oestrogens regulate the expression of human (h) Wnt-1 induced signalling pathway protein (WISP-2)/CCN5. Real-time RT-PCR showed that $\mathrm{hWISP}-2 / \mathrm{CCN} 5 \mathrm{mRNA}$ transcripts level is upregulated by oestrogens in the oestrogen receptor-positive human breast cancer cell lines MCF-7, T47D and ZR-75-1. Cloning of a $1.9 \mathrm{~kb}$ fragment of the hWISP-2/CCN5 5 '-flanking sequence and subsequent analysis of potential transcription factor-binding sites identified a functional oestrogen response element site

located between -581 and -569 upstream from the oestrogen-induced transcription start site. Transient transfections of MCF-7 cells with the cloned fragment showed that oestradiol caused an increase in reporter gene activity, which was inhibited by anti-oestrogens ICI 182780 and 4-hydroxytamoxifen. Chromatin immunoprecipitation analysis revealed an oestradiol-dependent recruitment of the oestrogen receptor $\alpha$ to the oestrogen- responsive region of the hWISP-2/CCN5 gene promoter. We also showed that endogenous CREB-binding protein $(\mathrm{CBP})$ and $\mathrm{p} 21^{\mathrm{WAF} 1 / \mathrm{CIP} 1}$ are recruited to the chromosomal hWISP-2/CCN5 promoter in MCF-7 cells in an oestrogen-dependent manner, suggesting that CBP and $\mathrm{p} 21^{\mathrm{WAF} 1 / \mathrm{CIP} 1}$ participate in the oestrogen receptor $\alpha$-mediated transcriptional control of the $h W I S P-2 / C C N 5$ gene.

Journal of Endocrinology (2006) 191, 613-624
\end{abstract}

\section{Introduction}

The human Wnt-1-induced signalling pathway protein-2 (WISP-2/CCN5) gene is located on chromosome $20 \mathrm{q} 12-$ q13.1 and encodes a protein belonging to the connective tissue growth factor/cysteine-rich 61/nephroblastoma overexpressed (CCN) family of growth factors that shares conserved modular domains and has been implicated in normal physiological and pathological processes (Brigstock 2003, Brigstock et al. 2003, Rachfal \& Brigstock 2005). Unlike CCN family members which encompass four structural modules with sequence homologies with insulinlike growth factor-binding proteins (IGF-BP), von Willebrand factor, thrombospondin and cystein knot (CT), WISP-2/CCN5 contains only three structural modules and lacks the CT-domain (Pennica et al. 1998, Brigstock 1999, 2003). The domain structure of WISP-2/CCN5 suggests that its function may be different from that of other $\mathrm{CCN}$ proteins. WISP-2/CCN5 has been identified as being located downstream of Wnt-1 signalling pathway relevant to the transformed cell phenotype in C57MG mouse mammary epithelial cells transformed by Wnt-1 (Pennica et al. 1998). However, while members of the Wnt signalling pathway have been implicated in the pathogenesis of breast and colon cancer, the rat ortholog of WISP-2/CCN5, rCop-1 was identified as a gene, whose expression became lost after cell transformation (Zhang et al. 1998). Moreover, WISP-2/ CCN5 was found underexpressed in human colon tumours (Zhang et al. 1998). The discrepancy between these data raise questions concerning the role of WISP-2/CCN5 in cell proliferation and carcinogenesis particularly in breast cancer. The function of WISP-2/CCN5 as an oncogene or a tumour suppressor may be tissue-specific and could be explained by the way WISP-2/CCN5 expression is modulated in a particular cellular context. Previous studies have demonstrated that the expression of human WISP-2/CCN5 is induced by serum and by oestrogens in the MCF-7 human breast cancer cells (Zoubine et al. 2001, Inadera et al. 2002, Banerjee et al. 2003). Moreover, Inadera et al. (2000) showed that the oestrogen-induced upregulation of human (h) WISP2/CCN5 was abolished by actinomycin D but not by cycloheximide treatment indicating a direct transcriptional control by oestrogen receptor (ER). Furthermore, the upregulation of WISP-2/CCN5 under oestrogen treatment could be independent of DNA synthesis (Inadera 2003) although it has been demonstrated that hWISP-2 is important for proliferation in MCF-7 cells (Banerjee et al. 2003, 2005). Recently, we demonstrated that hWISP-2/CCN5 mRNA 
transcripts were enhanced by $\mathrm{p} 21^{\mathrm{WAF} 1 / \mathrm{CIP} 1}$ in MCF-7 cells treated by oestrogens (Fritah et al. 2005). In these cells, the expression of $\mathrm{p} 21^{\mathrm{WAF} 1 / \mathrm{CIP} 1}$ induced cell cycle arrest and changes suggestive of mammary differentiation. Taken together, these results suggest that the expression levels of WISP-2/CCN5 may be a marker for breast cancer progression.

Oestrogens regulate the expression of genes involved in a wide variety of biological processes, including growth, differentiation and development in many target organs. Besides, their role in normal mammary cell physiology, oestrogens are also implicated in the development and progression of breast carcinoma. The biological effects of oestrogens are mediated through binding to their receptor proteins $\mathrm{ER} \alpha$ and $\mathrm{ER} \beta$, members of the steroid/thyroid nuclear receptor superfamily (Mangelsdorf et al. 1995, Delaunay et al. 2000). Like other members of the superfamily, ER exhibits a modular structure composed of three functional regions: the amino-terminal region containing the transactivation function. AF-1, the DNA-binding central domain (DBD) and the carboxylterminal region that encompasses the ligand-binding domain, dimerization surface and ligand-dependent transactivation function AF-2 (Gronemeyer 1991, Beato et al. 1995). Upon activation by hormone binding, the receptor interacts specifically with a cis-acting DNA sequence called the oestrogen response element (ERE), which is usually located upstream of the promoter and displays enhancer properties. For regulation of gene transcription, ER has to interact with basal transcription factors and RNA polymerase II (Jacq et al. 1994, Cavailles et al. 1995, Sabbah et al. 1998, Wu et al. 1999). The binding of the hormone to the receptor induces a conformational change in the hormone-binding domain allowing ER to bind co-activators, such as the p160/steroid receptor coactivator (SRC) family, the co-integrators p300/CBP and the p300/ $\mathrm{CBP}$-associated factor $\mathrm{p} / \mathrm{CAF}$, enhancing its transactivation potential (Rosenfeld \& Glass 2001). These co-activators function as bridging proteins for the components of the basal transcriptional machinery and/or as histone acetyltransferases that help to overcome the repressive effect of chromatin structure on transcription (Rosenfeld \& Glass 2001). In addition, ER can interact with other DNA-bound transcription factors to influence transcription activation (O'Lone et al. 2004).

The purpose of the present study is to gain insight into the molecular mechanism underlying the oestrogen-induced transcriptional control of the $h W I S P-2 / C C N 5$ gene. In this work, we show that hWISP-2/CCN5 mRNA transcripts level is upregulated by oestrogens in the three commonly used oestrogen receptor-positive breast cancer cell lines MCF-7, T47D and ZR-75.1. Moreover, we analyzed the hWISP$2 / \mathrm{CCN} 5$ gene promoter by using in vitro and in vivo approaches and we report the identification of a functional oestrogen response element involved in the regulation of the hWISP-2/CCN5 gene promoter by oestrogens. This element allows the recruitment of CBP and $\mathrm{p} 21^{\mathrm{WAF} 1 / \mathrm{CIP} 1}$ by $\mathrm{ER} \alpha$ to the chromosomal hWISP-2/CCN5 promoter in MCF-7 cells in an oestrogen-dependent manner.

\section{Materials and Methods}

\section{Cell culture}

MCF-7, T47D, ZR-75·1, SKBr3 human breast cancer cells and HeLa human epitheloid carcinoma cells were maintained in Dulbecco's modified Eagle's medium (DMEM) supplemented with $10 \%$ fetal bovine serum (FBS). MDA-MB-231 and DU4475 human breast cancer cells were maintained in RPMI-1640 medium supplemented with 10\% FBS.

\section{Plasmids}

The expression plasmids for full length human $\operatorname{ER} \beta$, human ER $\alpha$ (HEG0) and its fragments (HE19, HE15, HE11) have been described previously (Sabbah et al. 1998). For the promoter activity assays, the expression plasmid CMV- $\beta$ galactosidase was used as internal control for evaluation of the transfection efficiency. The reporter plasmid was Xenopus laevis vitellogenin A2 ERE-TK-Luc (Klock et al. 1987).

\section{Real-time RT-PCR}

MCF-7, T47D, ZR-75.1, MDA-MB-231, SKBr3 and DU4475 were grown in phenol red- and hormone freemedium supplemented with $10 \%$ dextran-charcoal stripped FBS for $48 \mathrm{~h}$ then cells were treated with vehicle, $10 \mathrm{nM}$ $17 \beta$-oestradiol (E2) with or without 100 nM ICI 182780 for $24 \mathrm{~h}$. Total RNA was extracted by using the RNeasy mini-kit (QIAGEN) with DNase I treatment according to the manufacturer's instructions. Then 500 ng total RNA were subjected to reverse transcription with $200 \mathrm{ng}$ random primers (Invitrogen) and ImProm-II reverse transcriptase (Promega) for $60 \mathrm{~min}$ at $42{ }^{\circ} \mathrm{C}$, in $20 \mu \mathrm{l}$ final volume. Two microliters RT reaction were diluted (1:10) and subjected to real-time PCR, using sequence-specific primers $(300 \mathrm{nM})$ and Brilliant SYBR GREEN QPCR master mix on an Mx3000P apparatus (Stratagene). The sequence-specific primers amplified a $99 \mathrm{bp}$ fragment of the hWISP-2/CCN5 target gene and were as follows: hWISP-2/CCN5, upper, 5'-CATGCAGAACACCAATATTAAC-3'; lower, $5^{\prime}$-TAGGCAGTGAGTTAGAGGAAAG-3'. To analyze the real-time PCR results obtained, the threshold was set above the no template control background and within the linear phase of target gene amplification to calculate the cycle number at, which the transcript was detected $(\mathrm{Ct})$. Seven housekeeping genes were analyzed and we evaluated the three most stable housekeeping genes (RPL13A, 36B4 and YWHAZ) to normalize the results obtained for the target gene $h W I S P$ 2/CCN5 as described in (Vandesompele et al. 2002). Briefly, gene expression $\mathrm{Ct}$ values were transformed to quantities with the highest relative quantities for each gene set to one. The geometric means of the quantities of the three most stable housekeeping genes were used to calculate the normalization factor. The results obtained after normalization represent the relative level of expression of the hWISP-2/CCN5 mRNA 
transcripts among the six different cell lines tested. In parallel, the RT- PCR products obtained after 33 cycles of amplification of the hWISP-2/CCN5 gene and the molecular marker Phi-X 174 Hae III (Invitrogen) were resolved and analyzed on 3\% agarose gel electrophoresis.

\section{Determination of the transcription start point}

To determine the transcription start point, we applied the rapid amplification of $5^{\prime} \mathrm{cDNA}$ end (RACE) procedure with the oligocapping method by using GeneRacer kit (Invitrogen) according to the manufacturer's instructions with $5 \mu \mathrm{g}$ total RNA isolated from MCF-7 cells, treated for $48 \mathrm{~h}$ with vehicle or $10 \mathrm{nM}$ E2 with or without $100 \mathrm{nM}$ ICI 182780 . PCR were performed by using the RACE outer gene-specific primer $5^{\prime}$-CTCTGCCAAGAGGCACAGGG- $3^{\prime}$ and the RACE inner gene-specific primer $5^{\prime}$-AGACGTGGAGTTGGTCGCAGG- $3^{\prime}$. The amplified fragments were resolved by agarose gel electrophoresis and cloned into the pCR4Blunt-TOPO vector (Invitrogen) for sequencing analysis.

Cloning of the hWISP-2/CCN5 gene promoter region and construction of hWISP-2/CCN5 gene promoter reporter plasmids

A pair of gene-specific primers, $\Delta$-1919: 5'-CACCGGCCCAGCTGTATTTC- $3^{\prime}$ and R6: 5'-GCAGAGCCAGCTTTGAGCCT- $3^{\prime}$ was designed to amplify the hWISP-2/CCN5 gene promoter region $(-1919$ to +13$)$ from genomic DNA isolated from MCF-7 cells by using platinum Pfx DNA polymerase (Invitrogen). The PCR-generated fragment was purified by agarose gel electrophoresis and cloned into the pCR4Blunt-TOPO vector (Invitrogen). The hWISP2/CCN5 gene promoter region was sequenced. Four synthetic luciferase reporter gene plasmids were constructed by inserting PCR fragments into the KpnI and BglII sites of the luciferase reporter pGL3-Basic vector (Promega). These PCR fragments were generated from the hWISP-2/CCN5 gene promoter region cloned into the pCR4Blunt-TOPO vector (Invitrogen) by using the common reverse primer R6 and the following forward primers $\Delta-1919$ (mentioned earlier), $\Delta$-808: $5^{\prime}$-TGTTGTGCCTCCAGCTCCTG-3', $\Delta-520: \quad 5^{\prime}$-GCTACCCAGAGTCAGGGCCA-3' and $\Delta$-422: 5'-GTTCGGACAGGGGGTCTGGA-3'. The four luciferase reporter plasmids obtained were denoted WISP2/CCN5 $\Delta$-1919, WISP-2/CCN5 $\Delta$-808, WISP-2/CCN5 $\Delta-520$ and WISP-2/CCN5 $\Delta-422$ respectively.

The template for mutagenesis was the luciferase reporter plasmid WISP-2/CCN5 $\Delta$-1919. Point mutations were created by using PCR-based oligonucleotide-directed mutagenesis by using Quick Change II site-directed mutagenesis kit (Stratagene) and a primer containing two-point mutations in the ERE of the hWISP-2/CCN5 gene promoter $5^{\prime}$-GaTCACACCCAtC-3' to yield the WISP-2/CCN5 $\Delta$-1919 mERE. PCR-generated fragments were sequenced. The WISP-2/CCN5 ERETK-Luciferase reporter plasmid was constructed by inserting the double-stranded oligonucleotide 5'-TTGCTCTGGGTCACACCCACCTCTGGGTG-3' corresponding to the -581 to -569 region of the hWISP-2/CCN5 gene promoter into the BamHI and HindIII sites of the -105 pTKFLuc reporter vector (kind gift from Dr F Gouilleux).

\section{Transient transfection}

For the promoter activity assays, MCF-7, HeLa and MDAMB-231 cells were plated in six-well plates in phenol red-free medium supplemented with $10 \%$ dextran-charcoal stripped FBS, $24 \mathrm{~h}$ prior to transfection. DNA was introduced into the cells by using FuGene 6 transfection reagent (Roche Molecular Biochemicals). After overnight incubation, cells were treated with $10 \mathrm{nM}$ E2 with or without $100 \mathrm{nM}$ ICI $182780,100 \mathrm{nM}$ 4-hydroxytamoxifen or ethanol vehicle $(0 \cdot 01 \%)$ and harvested $24 \mathrm{~h}$ later for the determination of luciferase and $\beta$-galactosidase activities.

\section{Western-blot}

Proteins from MCF-7 and MDA-MB-231 cells were extracted by using NTEN lysis buffer $(0 \cdot 5 \%$ NP40, $20 \mathrm{mM}$ Tris- $\mathrm{HCl}$ $\mathrm{pH} 8,1 \mathrm{mM}$ EDTA and $150 \mathrm{mM} \mathrm{NaCl})$. Then, $50 \mu \mathrm{g}$ protein extracts for each sample were separated by SDS-PAGE and transferred to nitrocellulose membranes. The membranes were blocked with saturating buffer for $1 \mathrm{~h}$ at room temperature followed by incubation with appropriate antibodies overnight at $4{ }^{\circ} \mathrm{C}$. Immunoblot analysis were performed by using antioestrogen receptor $\alpha$ (Ab-15, NeoMarkers, Fremont, CA, USA), anti-oestrogen receptor $\beta$ (ab16813, Abcam, Cambridge, UK), anti-phospho-oestrogen receptor $\boldsymbol{\alpha}$-directed against S118 (NL44, Upstate, Biotechnology Inc., Lake Placid, NY, USA) and anti-actine (I-19, Santa Cruz, Biotechnology, Santa Cruz, CA, USA). Membranes were then washed and incubated with horseradish peroxidase-conjugated secondary antibodies for $2 \mathrm{~h}$. Membranes were washed extensively and developed with an enhanced chemiluminescence kit (ECL, Amersham Pharmacia).

\section{Gel retardation assay}

Gel retardation assays were performed as previously described (Sabbah et al. 1996). The following double-stranded oligonucleotides for hWISP-2/CCN5 ERE: 5'-TTGCTCTGGGTCACACCCACCTCTGGGTG-3', hWISP-2/ CCN5 mERE: $5^{\prime}$-TTGCTCTGGATCACACCCATCTCTGGGTG-3' and Xenopus laevis vitellogenin A2 ERE: 5'-CAAAGTCAGGTCACAGTGACCTGATCAAA-3' were used.

\section{Chromatin immunoprecipitation (ChIP) assay}

MCF-7 cells were grown in phenol red-free DMEM supplemented with 5\% dextran-charcoal stripped FBS for three days and then treated for $45 \mathrm{~min}$ with vehicle or $100 \mathrm{nM}$ 
E2. ChIP assays were performed largely as previously described (Fritah et al. 2005). Briefly, a small portion (1\%) of the crosslinked, sheared chromatin solution was saved as input DNA and the remainder was used for immunoprecipitation by using specific anti-ER $\alpha$ antibody (AER-311; Upstate), anti-CBP antibody (A-22; Santa Cruz) or anti-p21 antibody (SX118; Pharmingen, BD Biosciences, Lincoln Park, NJ). Immunoprecipitated DNA was deproteinized, precipitated by ethanol and resuspended in $30 \mu \mathrm{l}$ water. Then $2 \mu \mathrm{l}$ DNA were subjected to PCR (30 cycles) by using the following primers pair for hWISP-2/CCN5 gene promoter amplification: upper, 5'-TGTTGTGCCTCCAGCTCCTG-3'; lower, 5'-GGTTTCTGGCAGGCAGATT-3'.

\section{Results}

hWISP-2/CCN5 expression is induced by oestrogens in ER-positive human breast cancer cell lines

It has been reported that hWISP-2/CCN5 expression is induced by oestrogens in the MCF-7 cell line (Inadera et al. 2002, Banerjee et al. 2003, Fritah et al. 2005). We wondered whether oestrogens regulate hWISP-2/CCN5 expression in two other ER-positive human breast cancer cell lines: T47D and $\mathrm{ZR}-75 \cdot 1$. For this purpose, we evaluated the hWISP-2/ CCN 5 mRNA level by real-time RT-PCR. The results show that the hWISP-2/CCN5 mRNA transcripts are induced by oestradiol to the same extent in the MCF-7 and T47D cell lines (about fourfold) and to a greater extent in $\mathrm{ZR}-75 \cdot 1$ cell line (sevenfold) (Fig. 1A). The oestrogen-mediated increase of the hWISP-2/CCN5 mRNA transcripts level in the three cell lines is antagonized by ICI 182780 , a pure oestrogen antagonist, confirming the specificity of the induction (Fig. 1A and B). In parallel, we analyzed the effects of oestrogens on the hWISP-2/CCN5 mRNA level in three ER-negative human breast cancer cell lines MDA-MB-231, SKBr3 and DU4475. As expected, the hWISP-2/CCN5 mRNA transcripts are not induced by oestrogens in these cell lines (Fig. 1A and B). We note a very low level of hWISP-2/ CCN5 mRNA transcripts in the MDA-MB-231 cell line (Fig. 1A and B). These results show that oestrogens induce hWISP-2/CCN5 expression in the three commonly used ER-positive human breast cancer cell lines MCF-7, T47D and $\mathrm{ZR}-75 \cdot 1$.

\section{Analysis of the human WISP-2/CCN5 gene promoter}

To identify the transcription start point of the $h W I S P$ 2/CCN5 gene, RACE analysis with the oligocapping method was performed on total RNA isolated from MCF7 cells treated with vehicle or oestradiol with or without ICI. Because the oligocapping method specifically labels the capped end of the mRNA, the $5^{\prime}$ end of the PCR amplicon was assumed to be the transcription start point of the gene. The amplification of two PCR products with a major one

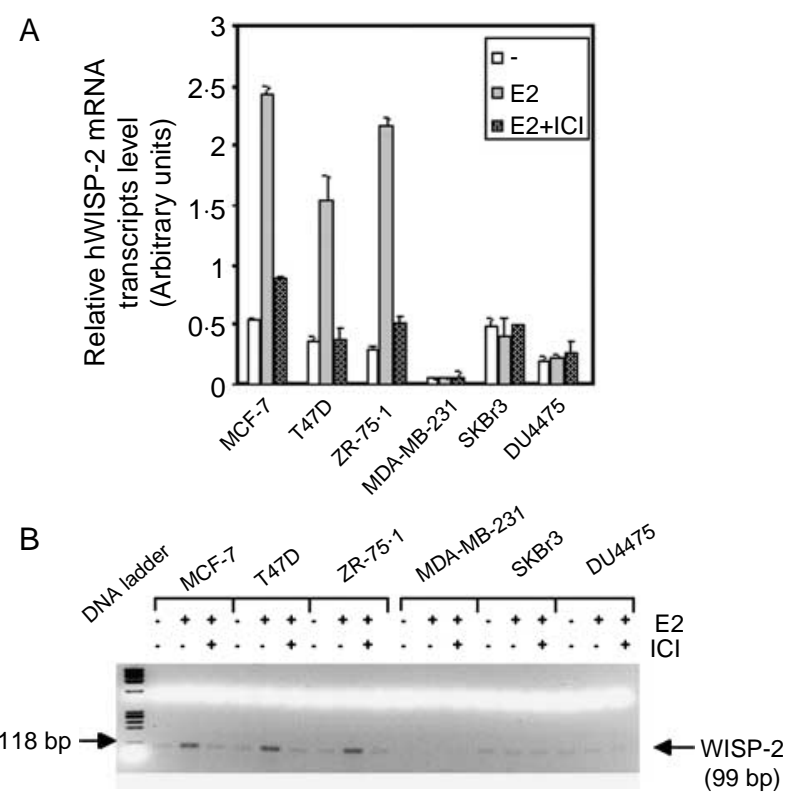

Figure $1 \mathrm{hWISP}-2 / \mathrm{CCN} 5$ expression is induced by oestrogens in ER-positive human breast cancer cell lines. (A) MCF-7, T47D, ZR$75 \cdot 1$, MDA-MB-231, SKBr3 and DU4475 were grown in phenol red- and hormone free-medium supplemented with $10 \%$ dextrancharcoal stripped FBS for $48 \mathrm{~h}$. Then cells were treated with vehicle, $10 \mathrm{nM}$ E2 with or without $100 \mathrm{nM} \mathrm{ICl} 182780$ (ICl) for $24 \mathrm{~h}$ as indicated. The mRNA transcript levels for hWISP-2/CCN5 were analyzed by real-time RT-PCR. The results after normalization, as described in Experimental Procedures, represent the relative hWISP-2/CCN5 mRNA transcripts levels among the six different cell lines tested and are the means \pm s.E.M. of duplicates. (B) The RT-PCR products obtained after 33 cycles of amplification were resolved and compared with the DNA ladder Phi-X 174 Hae III by using 3\% agarose gel electrophoresis. Results shown are representative of three independent experiments.

(indicated by an arrow in Fig. 2) were obtained from MCF-7 cells treated with oestradiol compared with MCF-7 cells treated with vehicle (Fig. 2). The amplification of the major PCR product obtained upon oestradiol treatment is abolished when MCF-7 cells are co-treated with ICI contrary to the second one, which is amplified in the same extent (Fig. 2). After cloning of the oestrogen-induced PCR product, the nucleotide sequence of the $5^{\prime}$ flanking region of the coding sequence of hWISP-2/CCN5 was determined for both strands. This analysis leads to the identification of one major transcription start point located at $21 \mathrm{bp}$ upstream from the first adenine residue of the translation initiation codon (Fig. 3). However, other transcription start sites exist and might be used by the gene to induce its transcription as suggested by our results and by the determination of full length sequences for hWISP-2/CCN5 mRNAs found in the NCBI database. We analyzed the sequence of the hWISP-2/ CCN5 promoter region next to the major transcription start point and found that it lacked canonical TATA-box or TATA-like motif. We conclude that $h W I S P-2 / C C N 5$ is a 


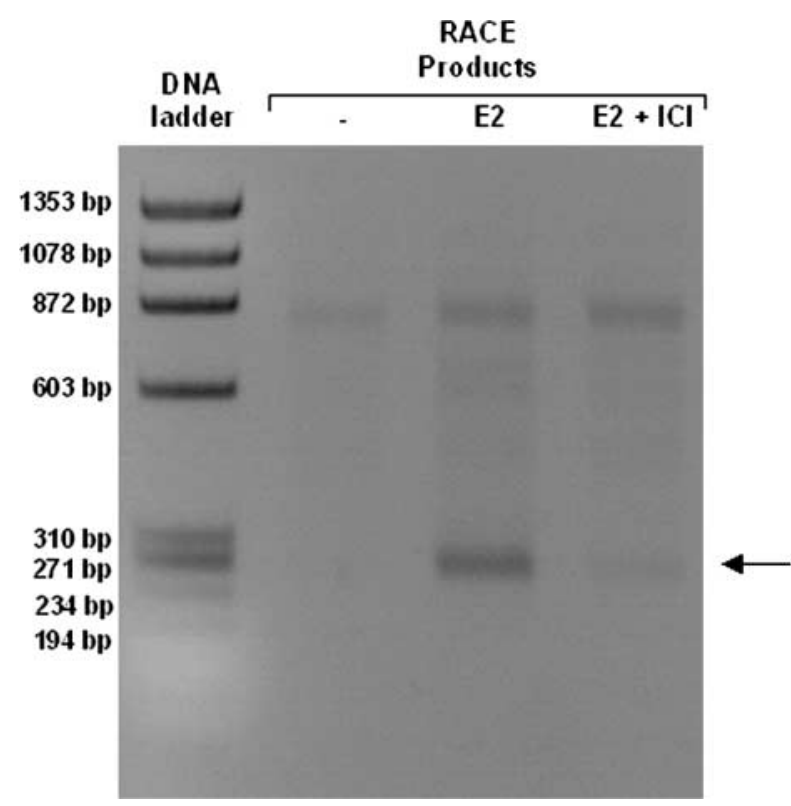

Figure 2 Determination of the transcription start point. RACE analysis with the oligocapping method was performed by using the GeneRacer kit with $5 \mu \mathrm{g}$ total RNA from MCF-7 cells treated with vehicle or $10 \mathrm{nM}$ E2 with or without ICI $182780(\mathrm{ICI})$ as indicated. Final PCR products were resolved and compared with the DNA ladder Phi-X 174 Hae III by using 2\% agarose gel electrophoresis. The major oestrogen-induced PCR product obtained is indicated by an arrow.

TATA-less gene but initiates transcription from one major site under oestrogen treatment, in MCF-7 cells. The major transcription start point maps to a $\mathrm{TC}\left(\mathrm{A}_{+1}\right) \mathrm{AAGC}$ motif. This is homologous to the initiator consensus sequence of $\operatorname{PyPy}\left(\mathrm{A}_{+1}\right) \mathrm{N}(\mathrm{T} / \mathrm{A}) \operatorname{PyPy}$ (Javahery et al. 1994, Lo \& Smale 1996). By using the TRANSFAC database, a closer inspection of the hWISP-2/CCN5 promoter sequence further upstream, revealed the presence of a number of potential-binding sites which might be implicated in oestrogen signalling as one putative ERE-binding site, two ERE half-binding sites, three AP1- and Sp1-binding sites. Moreover, it revealed the presence of six putative T-cell factor (TCF)-binding sites which might be implicated in the wnt-1 signalling pathway and one nuclear factor-kappa B (NF- $\kappa \mathrm{B})-$ binding site and one CRE-binding site, which might be implicated in the regulation of hWISP-2/CCN5 expression by serum (Fig. 3).

Induction of the hWISP-2/CCN5 gene promoter by oestrogens can be selectively blocked by antagonists and requires the presence of the wild-type ER $\alpha$

To examine whether the hWISP-2/CCN5 gene promoter did indeed confer oestrogen inducibility, we measured the WISP-2/CCN5 $\Delta-1919$ promoter activity in the MCF-7 cell line. We found that oestradiol upregulates hWISP2/CCN5 promoter activity four- to fivefold compared with untreated control (Fig. 4A). To determine the specificity of the oestrogen induction of the hWISP-2/ CCN5 gene promoter, we tested whether two oestrogen antagonists, 4-hydroxytamoxifen and ICI 182780 could block this response. ICI 182780 is a pure oestrogen antagonist which blocks both ER-transactivating functions AF-1 and AF-2. In the presence of 4-hydroxytamoxifen, a mixed agonist/antagonist, the receptor transactivates through the AF-1 domain, while the AF-2-transactivating domain of ER is blocked in MCF-7 cells. The results show that neither of these two antagonists stimulated the hWISP-2/CCN5 gene promoter activity (Fig. 4A). Furthermore, addition of these antagonists simultaneously with oestradiol completely blocked the oestrogen-induced stimulation (Fig. 4A). These results indicate that the induction of the hWISP-2/CCN5 gene promoter requires agonist-activated ER.

There are two distinct subtypes of ER so to compare the ability of ER $\alpha$ and ER $\beta$ to regulate the hWISP-2/CCN5 gene promoter, we used the ER-negative cell line MDAMB-231. Upon oestradiol treatment, ER $\beta$ induces the hWISP-2/CCN5 promoter luciferase construct (twofold) but to a lesser extent than ER $\alpha$ (3.5-fold) (Fig. 4B). Transfection efficiency of ER $\alpha$ and ER $\beta$ in MDA-MB-231 cells was confirmed by western blot analysis (Fig. 4C). Phosphorylation at $\operatorname{Ser}^{118}$ is associated with activation of ER $\alpha$ and can be potentiated by oestradiol (Chen et al. 2000, 2002) so the activity of $E R \alpha$ was confirmed by determining phosphorylation at $\mathrm{Ser}^{118}$ in ER $\alpha$-transfected MDA-MB-231 cells. Phosphorylation of ER $\alpha$ is detected in ER $\alpha$-transfected MDA-MB-231 cells (Fig. 4C). Then we evaluated the effect of oestradiol on phosphorylation at Ser ${ }^{118}$ in MCF-7 and ER $\alpha$-transfected MDA-MB-231 cells. Oestradiol induces ER $\alpha$ phosphorylation in MCF-7 cells as previously described (Chen et al. 2000, 2002), whereas no change is observed in ER $\alpha$-transfected MDA-MB-231 cells (Fig. 4C). These results showing a differential effect of oestradiol on ER $\alpha$ phosphorylation are in agreement with those obtained in the same human breast cancer models with EGF (Banerjee et al. 2005). Since, $E R \alpha$ is the predominant endogenous isoform in MCF-7 cells, we wanted to gain insight into which domains of $E R \alpha$ are implicated. For this purpose, we tested the effects of truncated mutants of ER $\alpha$ (Fig. 4D) on oestrogen-induced activation of the hWISP-2/CCN5 gene promoter activity, in the ER-negative HeLa cell line (Fig. 4E). Previous work has established that each of these truncated mutants of ER $\alpha$ is expressed at comparable levels from these vectors (Kumar et al. 1987). Exogenous ER $\alpha$ (HEG0) induces the oestrogen upregulation of the WISP-2/CCN5 $\Delta-1919$ promoter activity (Fig. 4E). HE19, which contains the DBD, the ligand-binding domain and the hormone-inducible transactivating function $\mathrm{AF}-2$, was inefficient at stimulating transcription from the hWISP-2/CCN5 gene promoter, whereas it was an efficient inducible activator from the 
-1919 caccggccca gctgtatttc tgtgtttaaa cagtagagtg aaatcaacta tgaacgcaga atgatgggaa

-1849 agatgacgat aagggtattt caattttgtc attttacgaa actacttgga gttttgattt gtatttacag

-1779 tttttaaag agtaaaacag tgtgaactgt gaatggtaat gattttgttt ggtaagtgca aatttaatt

-1709 catacatgaa aaatattgt tttgtttcat gattattact gaaataatt ttgtactatg aaggaagagg

-1639 ggtgttaaaa atgatccact gtggatgtaa attattctag gcatgcttct gactaaaaca ttagcattc

AP1

-1569 cacaagaatc ccaaaaata aaacaaaatt taaagatcc cttctgtttc ttttcctcca agtttccaga

-1499 ccccatctc caccetggcc acctcttcct gccataata atcaaatccc acacttcat cttcaccttc

-1429 cgtttccatt gectcttccg atgggacagc acccgtgggg aatctcctcc atgctcacaa tcccgtctt

NFKB

-1359 gccactatat caagtcacac ttcttcctca ccaatcgccc attctggaac ctctgctatc cagctagatc

-1289 actttgaggt ttggacaact actggtggag gtaatggggg ccccagacag cccttgacat cacctcttt TCF

AP1

-1219 atctttgcca aattctacaa acaaagccca tgtctttctg tccccgecc ccatggetgg cacatagtag

TCF TCF Sp1

-1149 atgtccccaa atcttggtga tgtgaacttg tgtgtctcac ccttcacaga catcaccatt tcccgttgca

-1079 cagaaggctc cactcatacc aggcgctttg gctcccagaa taagcaggct atcatgctat gtccgacatc TCF

-1009 taggcgttgg tacgtactgt tcccttggcc tggaacattc tgccetctct caccetctct tttcttggct

-939 ttctgaaatg gcacctccat cagaaagtgt ccctcactct tggtctgagc aagggacct gectggtatt

-869 cctgaacttc cacctgttt ccctctgttt tctccctctc tgggcettgt cctcaggtca gtgttgtgcc half ERE

-799 tccagctcct gcagaggcga actcagaggc ggccgaatga aaccaaatgg atttggcttg acccatcat Sp 1

-729 ctagcggtgc ccagcaagcg ctggcacata gtaggtccag cetgccegga ctcgcccacc acgggeccc

-659 ttccagagcc gggaggcagg ccaagggagg cccttattg ccaagagcaa acaggocgcc cagggaagtt

Sp1

-589 ttgctctggg tcacacccac ctctgggtgg ctgccaatct gcctgccaga aaccgcaggc tgggccgcgg ERE

-519 ctacccagag tcagggccac ggagcttagg agaccttggg tcagctctgc aaaggggttg tttactgaat AP1 half ERE TCF

-449 gcttctggta tctgcagcce cgctggggtt cggacagggg gtctggaata gggcttcaca actacagcag

-379 ggctaggacc ctcttgggct ggaaggagct ggagaggcct ctgcaagctg tcacaggctc ttggtgctgg

-309 cactggetca ggctttcaca cacacacacg cgcacacaca cacacacaca cacacacgga caggcaccc

-239 cttggtggcc ttcacagttt caccttcagg taaatgggct catcctttga gccatgagga tgggaagcga

TCF

-169 agcaaggaat gaaaaagcta gtgtgtttgt gtgtgtgtgt gtgtgtgtgt gtgtgtgtgt gtgtgcacgc

-99 gegcgcgcgc gtgtgtacgc gtgcgtgtgc ctgtgtgtgc ctgggagtga cctcacagct gccggaacat

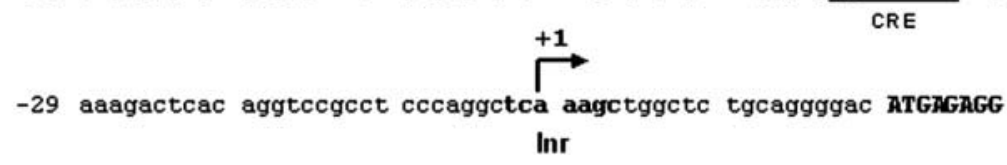

Figure 3 Nucleotide sequence of the hWISP-2/CCN5 gene promoter region. The transcription start point is denoted as +1 and the initiator motif $(\mathrm{Inr})$ is in bold case and underlined. The first nucleotides corresponding to the coding region are in bold case. The numbers shown to the left are relative to the transcription start point. Sequences for the three putative AP1-binding sites, the putative NF- $\kappa B$-binding site, the six putative TCF-binding sites, the three putative Sp1-binding sites, the two putative half ERE-binding sites, the putative ERE-binding site and the putative CRE-binding site are denoted and underlined.

Xenopus laevis vitellogenin A2 ERE-TK-Luc used as control (Fig. 4E). HE15, which contains the DBD and the constitutively active domain AF-1 but lacks the ligandbinding domain, was inefficient at stimulating transcription from both promoters (Fig. 4E). The receptor DBD is also necessary for oestrogen action as deletion of this domain
(HE11) abolished the induction (Fig. 4E). Similar results were obtained by using the MDA-MB-231 cell line (Fig. 4F). Collectively, these results demonstrate that the DBD is required and both $\mathrm{AF}-1$ and $\mathrm{AF}-2$ have to cooperate to obtain the full oestrogen induction of the hWISP-2/CCN5 gene promoter activity. 

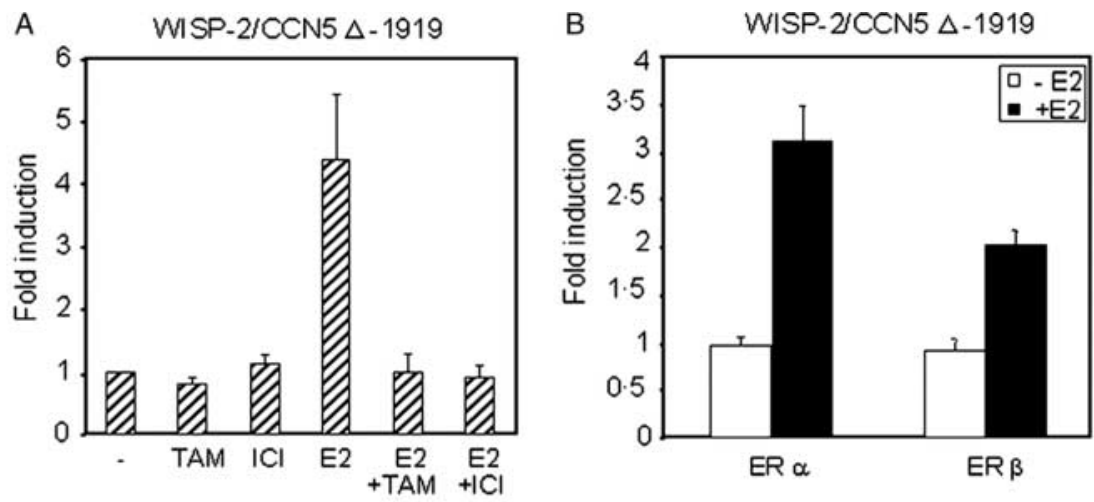

C
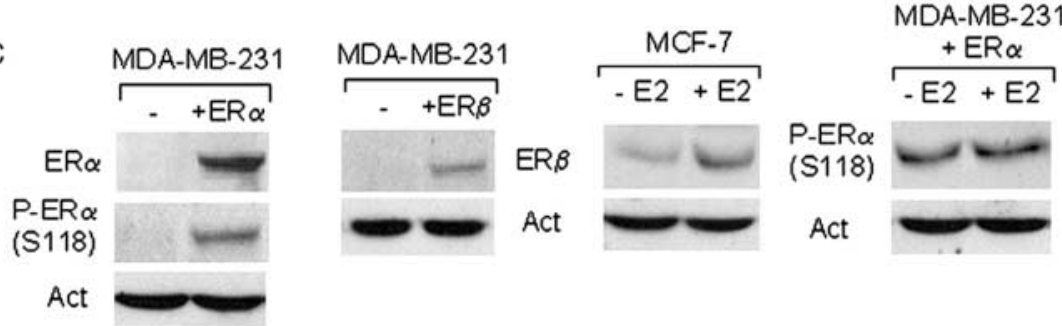

\begin{tabular}{r|r|c|c|c|c|}
\hline D HEG0 & $\mathrm{AB}$ & $\mathrm{C}$ & $\mathrm{D}$ & $\mathrm{E}$ & $\mathrm{F}$ \\
\hline HE19 & $\mathrm{C}$ & $\mathrm{D}$ & $\mathrm{E}$ & $\mathrm{F}$ \\
\cline { 2 - 4 } &
\end{tabular}

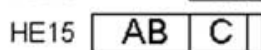

\begin{tabular}{lll|l|l|l|l|l|l|l|l|l|l|l}
\hline$A B$ & $A B$ & $E$ & $F$ \\
\hline
\end{tabular}
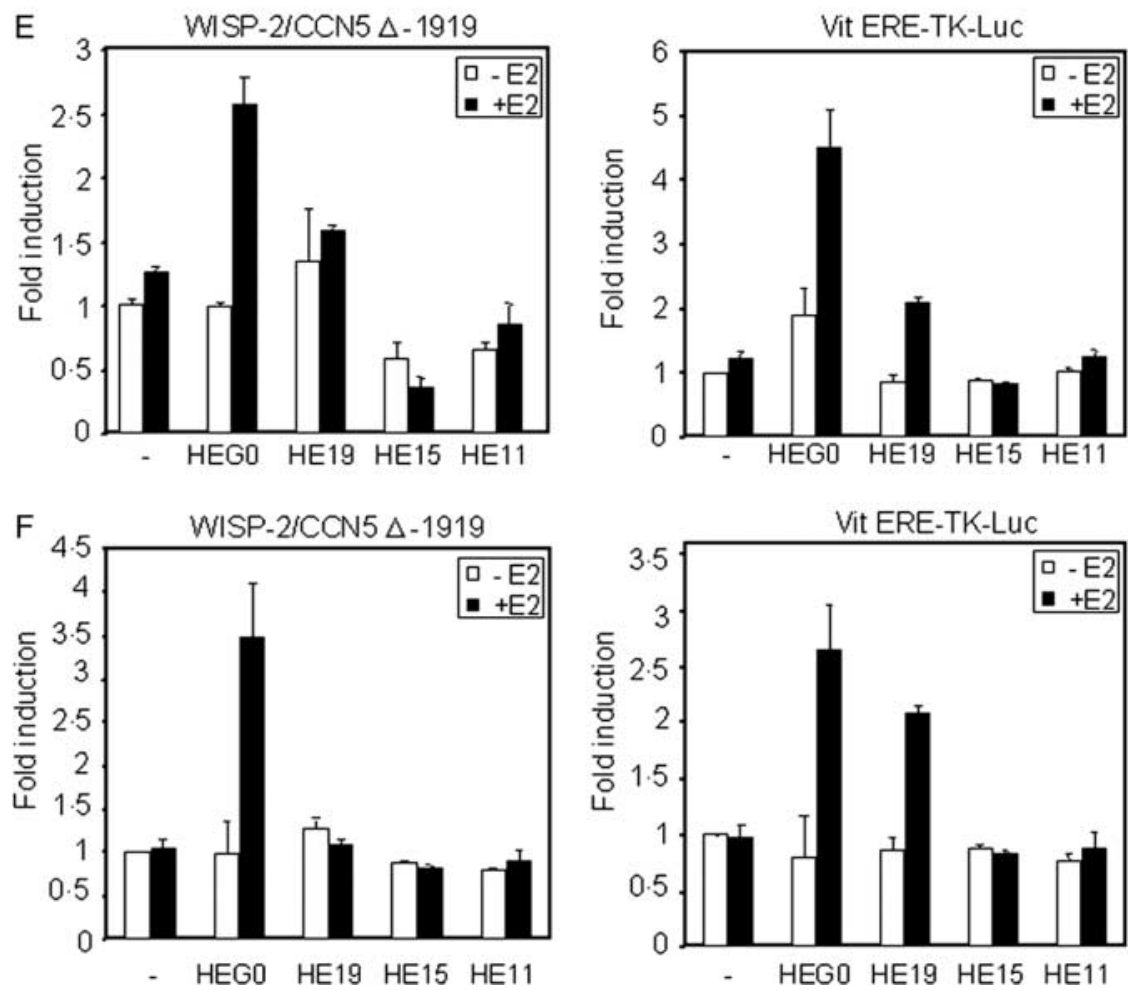
The ERE motif in the hWISP-2/CCN5 promoter confers oestrogen inducibility

To identify the oestrogen-responsive region in the hWISP2/CCN5 gene promoter, we generated serial deletion constructs (Fig. 5A). The deleted reporter constructs were transfected into MCF-7 cells. The oestrogen-induced activity of the WISP-2/CCN5 $\Delta-808$ was only partially affected as $80 \%$ of the maximal induction observed for the WISP-2/CCN5 $\Delta$-1919 was conserved (Fig. 5B), although it appeared that this deletion reduced the basal activity of the hWISP-2/CCN5 gene promoter. In contrast, additional deletions prevented oestradiol induction of both constructs WISP-2/CCN5 $\Delta-520$ and WISP-2/CCN5 $\Delta-422$, while restoring the basal activities of both constructs to the same extent as for the WISP-2/CCN5 $\Delta-1919$ (Fig. 5B). We conclude that the -808 to -520 region is responsible for the oestrogen stimulation. Since, one putative ERE $\left(5^{\prime}\right.$-GGTCACACCCACC- $\left.3^{\prime}\right)$ resides in this region, we hypothesized that this site was the most potent to confer oestrogen upregulation to the hWISP-2/CCN5 gene promoter. In agreement with this hypothesis, we generated mutation of the ERE motif by site-directed mutagenesis with an oligonucleotide containing two-point mutations $\left(5^{\prime}\right.$-GaTCACACCCAtC-3') reported to lead a loss of oestrogen responsiveness for the Xenopus laevis vitellogenin A2 ERE-TK-Luc, in transient transfection assays (Klock et al. 1987, Sabbah et al. 1991). Mutation of the ERE site in the WISP-2/CCN5 $\Delta-1919$ totally prevented the oestradiol induction of the hWISP-2/CCN5 gene promoter (Fig. 5C). These results demonstrate that the presence and the integrity of the ERE are necessary to confer oestrogen inducibility to the hWISP-2/CCN5 gene promoter. To determine if the ERE identified is sufficient to confer oestrogen stimulation, we constructed a WISP-2/CCN5 ERE-TK-Luc plasmid to test the capacity of the WISP-2/CCN5 ERE to drive the transcription of an heterologous promoter. The construct was introduced into MCF-7 cells treated with oestradiol or vehicle. The results obtained show that oestradiol upregulates the activities of both the WISP-2/CCN5 ERE-TK-luc (three- to fourfold) and the WISP-2/CCN5 $\Delta$-1919 (fourto fivefold) (Fig. 5D). Together, these results suggest that although the motif identified here (5'-GGTCACACCCACC $\left.-3^{\prime}\right)$ is imperfect when compared with the consensus sequence $\left(5^{\prime}\right.$-GGTCANNNTGACC- $\left.3^{\prime}\right)$ it is a functional oestrogen response element by itself responsible for the oestrogen-induced stimulation of the hWISP-2/ CCN5 gene promoter.

\section{$E R \alpha$ associates with the ERE identified in the hWISP-2/ CCN5 gene promoter in vitro}

To assess the ability of ER $\alpha$ to interact with the ERE identified in the hWISP-2/CCN5 gene promoter, we performed gel retardation assays. ${ }^{32} \mathrm{P}-$ labelled oligonucleotides corresponding to the -589 to -561 region of the hWISP-2/CCN5 gene promoter were incubated with increasing amounts of purified recombinant baculovirusexpressed human ER $\alpha$ (HEG0). The results show a dosedependent formation of higher order protein-DNA complexes (Fig. 6, lanes 1-3). The complexes formed were supershifted with a specific antibody to the human ER $\alpha$, confirming that they contained ER $\alpha$ (Fig. 6, lane 4). Competition experiments indicated that a 500 -fold molar excess of the same unlabelled oligonucleotide or unlabelled oligonucleotide containing the sequence of the Xenopus laevis vitellogenin A2 ERE displaced the retarded bands observed with the labelled oligonucleotide (Fig. 6, lanes 5-6), whereas a 500 -fold molar excess of the WISP-2/CCN 5 mutated ERE unlabelled oligonucleotide did not compete for the association of ER $\alpha$ with the labelled wild-type WISP-2/ CCN5 ERE-containing oligonucleotide (Fig. 6, lane 7). Moreover, we failed to detect any higher order proteinDNA complexes when incubating ${ }^{32} \mathrm{P}$-labelled mutated ERE oligonucleotide for hWISP-2/CCN5 with HEG0 (Fig. 6, lanes 8-9). The bands observed in gel retardation assays reflect a highly specific binding of the ER $\alpha$ to the ERE we identified, confirming the implication of this motif in the oestrogen regulation of the hWISP-2/CCN5 gene promoter.

\begin{abstract}
Figure 4 Induction of the hWISP-2/CCN5 gene promoter by oestrogens can be selectively blocked by antagonists and requires the presence of the wild-type ER $\alpha$. (A) MCF-7 cells were transiently co-transfected with $0.5 \mu \mathrm{g}$ WISP-2/CCN5 $\Delta$-1919 reporter luciferase construct and $0 \cdot 1 \mu \mathrm{g}$ plasmid expressing $\beta$-galactosidase as internal control. After transfection, cells were incubated with vehicle, $100 \mathrm{nM} 4$ hydroxytamoxifen (TAM), $100 \mathrm{nM} \mathrm{ICI} 182780(\mathrm{ICI})$ or $10 \mathrm{nM} \mathrm{E2}$ with or without TAM and ICI for $24 \mathrm{~h}$ as indicated and assayed for luciferase and $\beta$-galactosidase activities. (B) MDA-MB-231 cells were transiently co-transfected with $0 \cdot 5 \mu \mathrm{g}$ WISP-2/CCN5 $\Delta-1919$ reporter luciferase construct, $0 \cdot 1 \mu \mathrm{g}$ plasmids expressing human ER $\alpha$ or ER $\beta$ and $0 \cdot 1 \mu \mathrm{g}$ plasmid expressing $\beta$-galactosidase as internal control. After transfection, cells were incubated with vehicle or $10 \mathrm{nM} \mathrm{E2}$ for $24 \mathrm{~h}$ as indicated and assayed for luciferase and $\beta$-galactosidase activities. (C) $50 \mu \mathrm{g}$ proteins extracted from MDA-MB-231 cells transfected with vectors expressing ER $\alpha$, ER $\beta$ or the empty vector were separated by SDS-PAGE and transferred to nitrocellulose membranes. Membranes were blotted with antibodies directed against ER $\alpha$, ER $\beta$, phospho-ER $\alpha$ (P-ER $\alpha$ S118) and actin (Act). Proteins, $50 \mu \mathrm{g}$, extracted from MDA-MB-231 cells transfected with vector expressing ER $\alpha$ or from MCF-7 cells treated or not with $10 \mathrm{nM}$ E2 were separated by SDS-PAGE and transferred to nitrocellulose membranes. Membranes were blotted with antibodies directed against phospho-ER $\alpha$ (P-ER $\alpha$ S118) and actin (Act). (D) Schematic representation of the different mutants of ER used in this study. HeLa (E) or MDA-MB-231 (F) cells were transiently co-transfected with $0.5 \mu \mathrm{g}$ WISP-2/CCN5 $\Delta$ - 1919 reporter luciferase construct or Vit ERE-TK-Luc and $0 \cdot 1 \mu \mathrm{g}$ plasmids expressing human ER $\alpha$ (HEG0) or different regions of ER $\alpha$, HE19, HE15 and $\mathrm{HE} 11$ and $0 \cdot 1 \mu \mathrm{g}$ plasmid expressing $\beta$-galactosidase as internal control. After transfection, cells were incubated with vehicle or $10 \mathrm{nM}$ E2 for $24 \mathrm{~h}$ as indicated and assayed for luciferase and $\beta$-galactosidase activities. The results shown represent the average of three independent experiments assayed in duplicate.
\end{abstract}


A
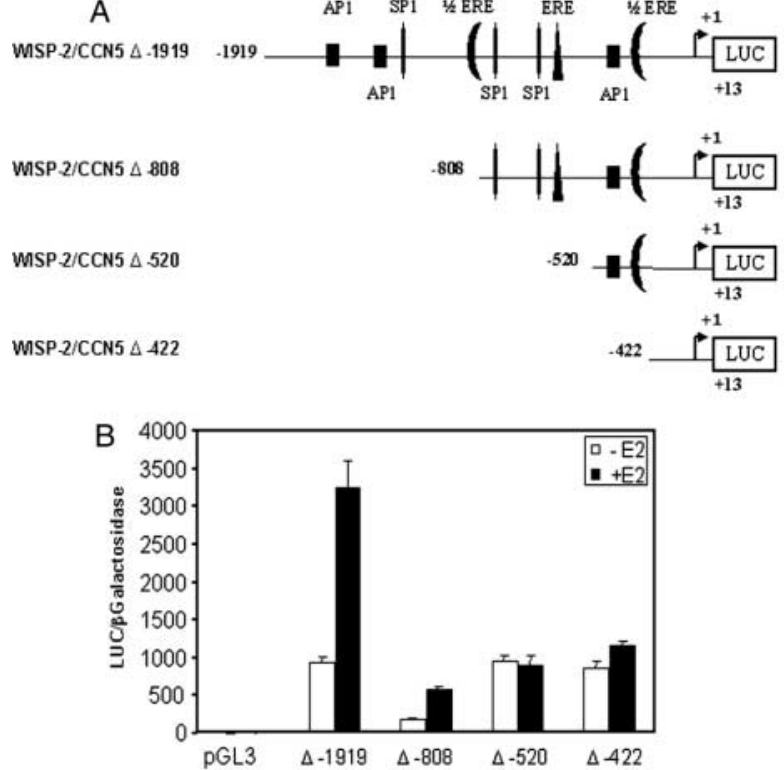

C
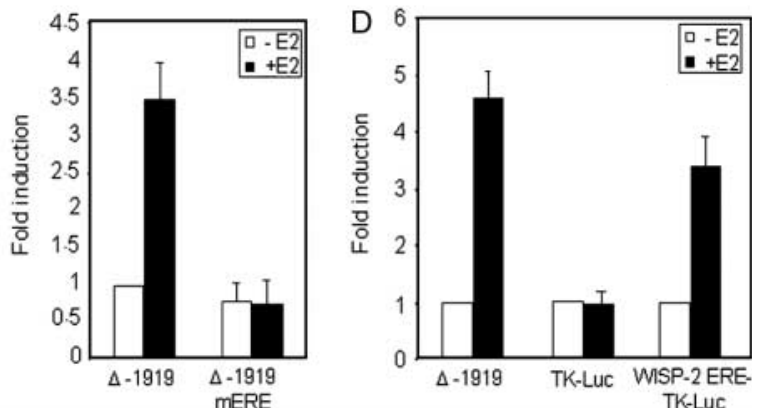

Figure 5 The ERE motif in the hWISP-2/CCN5 promoter confers oestrogen inducibility. (A) Schematic representation of the different hWISP-2/CCN5 promoter-luciferase reporter constructs used in this study: WISP-2/CCN5 $\Delta$-1919 ( $\Delta$-1919), WISP-2/CCN5 $\Delta$-808 $(\Delta-808)$, WISP-2/CCN5 $\Delta-520(\Delta-520)$ and WISP-2/CCN5 $\Delta-422$ $(\Delta-422)$. (B) MCF-7 cells were transiently co-transfected with $0 \cdot 5 \mu \mathrm{g}$ luciferase reporter pGL3-Basic vector or each hWISP-2/CCN5 promoter-luciferase reporter construct and $0 \cdot 1 \mu \mathrm{g}$ plasmid expressing $\beta$-galactosidase as internal control. (C) MCF-7 cells were transiently co-transfected with $0.5 \mu \mathrm{g}$ WISP-2/CCN5 $\Delta-1919$ $(\Delta-1919)$ or WISP-2/CCN5 $\Delta$-1919 mERE $(\Delta-1919 \mathrm{mERE})$ and $0 \cdot 1 \mu \mathrm{g}$ plasmid expressing $\beta$-galactosidase as internal control. (D) MCF-7 cells were transiently co-transfected with $0.5 \mu \mathrm{g}$ WISP-2/CCN5 $\Delta$-1919 $(\Delta-1919)$, TK-Luc or WISP-2/CCN5 ERE-TK-Luc together with $0 \cdot 1 \mu \mathrm{g}$ plasmid expressing $\beta$-galactosidase as internal control. (B-D) After transfection, cells were treated with vehicle or $10 \mathrm{nM} \mathrm{E2}$ for $24 \mathrm{~h}$ as indicated and assayed for luciferase and $\beta$-galactosidase activities. The results represent the average of three independent experiments assayed in duplicate.

Endogenous $p 21^{\text {WAF1/CIP1 }}$ and CBP participate at the ER $\alpha$ mediated transcriptional control of the hWISP-2/CCN5 gene in MCF-7 cells

To address the question whether endogenous ER $\alpha$ is recruited to the hWISP-2/CCN5 gene promoter in vivo, we performed a chromatin immunoprecipitation assay by using an ER $\alpha$-specific antibody. The recruitment of

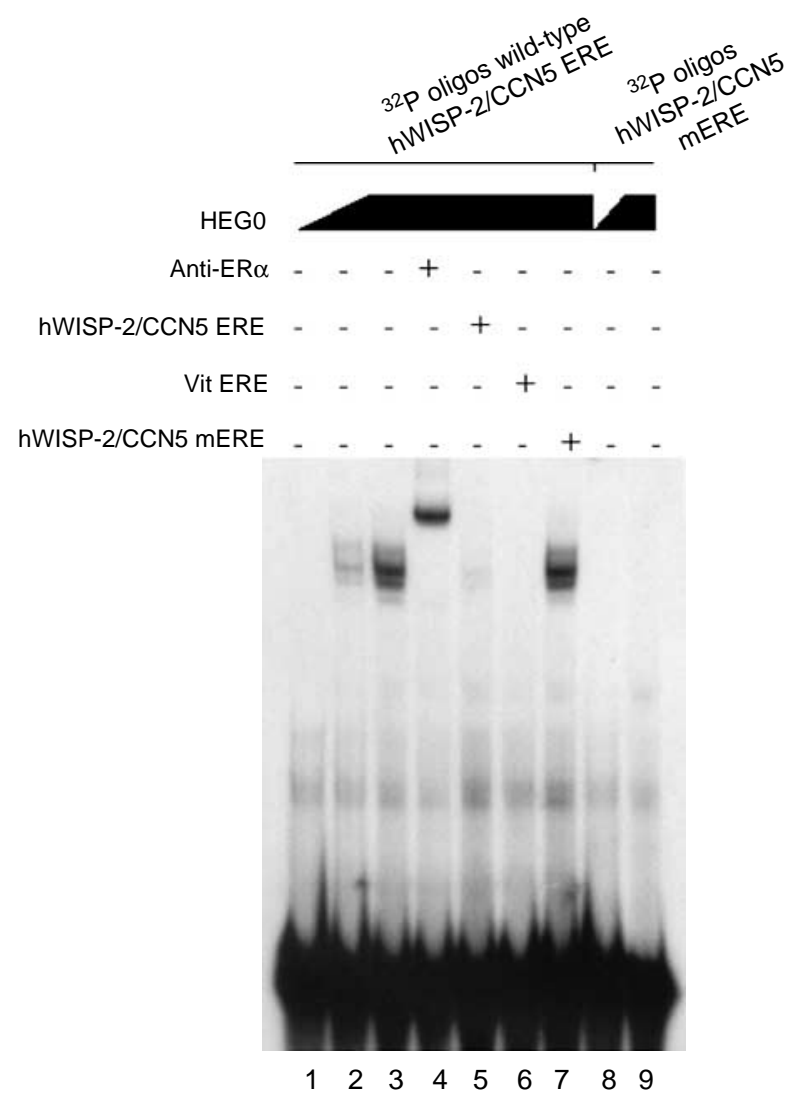

Figure $6 \mathrm{ER} \alpha$ associates with the ERE identified in the hWISP2/CCN5 gene promoter in vitro. Gel retardation assays were performed by using ${ }^{32} \mathrm{P}$-labelled oligonucleotides corresponding to the -581 to -569 region of the wild-type hWISP-2/CCN5 gene promoter (lanes 1-7) or the same region containing the mutated ERE (mERE) (lanes 8-9) incubated with increasing amounts of HEG0 (lanes 1-7, 8-9). Anti-ER $\alpha$ antibody, H222 (Abbott Laboratory), were used to supershift the ER $\alpha$-containing complexes, lane 4. Specificity of the complexes was also determined by using a 500molar excess of cold DNA as follows: wild-type hWISP-2/CCN5 ERE oligonucleotides (lane 5), Xenopus laevis vitellogenin A2 EREcontaining oligonucleotides (Vit ERE) (lane 6), hWISP-2/CCN5 mERE oligonucleotides (lane 7). Results shown are representative of three independent experiments.

endogenous $\mathrm{ER} \alpha$ to the hWISP-2/CCN5 gene promoter was examined in MCF-7 cells after a 45 min oestradiol treatment. The results show that oestradiol induces a significant increase in ER $\alpha$ occupancy of the -808 to -536 region of the hWISP-2/CCN5 gene promoter containing the ERE (Fig. 7). The presence of ER $\alpha$ in the absence of stimulation by oestradiol can be attributed to the binding of $\mathrm{ER} \alpha$ to DNA in vitro and in vivo even in the absence of ligand (Sabbah et al. 1991, Shang et al. 2000, Reid et al. 2003). As expected, we did not observe any significant increase in ER $\alpha$ occupancy of the coding region of the hWISP-2/CCN5 gene as negative control (Fig. 7). In addition, chromatin immunoprecipitation assay performed using non-immune $\operatorname{IgG}$ as control failed to show any 

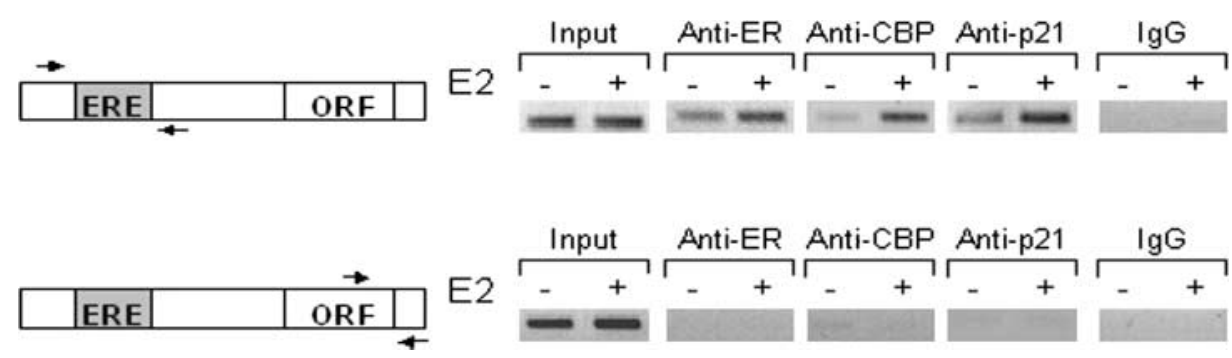

Figure 7 Endogenous $\mathrm{p} 21^{\mathrm{WAF} 1 / \mathrm{CIP} 1}$ and CBP participate in the ER $\alpha$-mediated transcriptional control of the hWISP-2/CCN5 gene in MCF-7 cells. Crosslinked, sheared chromatin from MCF-7 cells treated with vehicle or saturating levels of E2 for 45 min, was immunoprecipitated with the indicated specific antibodies. Immunoprecipitated DNA was deproteinized, precipitated by ethanol and resuspended. Then DNA was analyzed by PCR, by using primers to amplify the hWISP-2/CCN5 promoter region containing the identified ERE or the coding region of the $h W I S P-2 / C C N 5$ gene as negative control. Results shown are representative of three independent experiments.

amplification of the hWISP-2/CCN5 gene promoter region containing the ERE (Fig. 7). These results show that endogenous ER $\alpha$ is recruited to the hWISP-2/CCN5 gene promoter in an oestrogen-dependent manner.

Previously, we showed that the oestrogen-induced expression of the hWISP-2/CCN5 and progesterone receptor mRNA transcripts in MCF-7 cells was enhanced by p21 WAF1/CIP1 (Fritah et al. 2005). Moreover, chromatin immunoprecipitation assays revealed that endogenous $\mathrm{p} 21^{\mathrm{WAF} 1 / \mathrm{CIP} 1}$ was recruited simultaneously with $\mathrm{ER} \alpha$ and CBP to the endogenous progesterone receptor gene promoter in an oestrogendependent manner. To determine whether endogenous p21 WAF1/CIP1 and CBP act directly on the hWISP-2/CCN5 promoter, we performed chromatin immunoprecipitation assays by using specific antibodies to $\mathrm{p} 21^{\mathrm{WAF} 1 / \mathrm{CIP} 1}$ and CBP. We observed the oestrogen-induced recruitment for endogenous CBP and $\mathrm{p} 21^{\mathrm{WAF} 1 / \mathrm{CIP} 1}$ in a manner similar to the recruitement of ER $\alpha$ on the hWISP-2/CCN5 gene promoter (Fig. 7). As for $\mathrm{ER} \alpha$, we did not detect any significant increase in CBP or $\mathrm{p} 21^{\mathrm{WAF} 1 / \mathrm{CIP} 1}$ occupancy of the coding region of the hWISP-2/CCN5 gene (Fig. 7). We can conclude that endogenous $\mathrm{p} 21^{\mathrm{WAF} 1 / \mathrm{CIP} 1}$ and CBP are recruited concomitantly to ER $\alpha$ in an oestrogen-dependent manner to the hWISP-2/CCN5 gene promoter suggesting that $\mathrm{p} 21^{\mathrm{WAF} 1 / \mathrm{CIP} 1}$ and CBP participate at the ER $\alpha$-mediated control of the hWISP-2/CCN5 gene expression in MCF-7 cells.

\section{Discussion}

Oestrogens are decisive actors responsible for the proliferation and differentiation of normal mammary epithelial cells, as well as for progression of breast cancer. Oestrogens regulate the expression of many target genes but in fact few genes are known to be directly induced by the association of liganded ER - to ERE-containing binding sites. In the present study we demonstrate that the oestrogen-induced expression of hWISP-2/CCN5, a member of the CCN family of growth factors, is mediated through the interaction of $\mathrm{ER} \alpha$ with a functional oestrogen response element present in the
hWISP-2/CCN5 gene promoter. Furthermore, we show that endogenous $\mathrm{CBP}$ and $\mathrm{p} 21^{\mathrm{WAF} 1 / \mathrm{CIP} 1}$ are recruited simultaneously to $\mathrm{ER} \alpha$ in an oestrogen-dependent manner to the hWISP-2/CCN5 gene promoter.

We focused our attention on the oestrogen-induced activation of the hWISP-2/CCN5 gene promoter by the $\mathrm{ER} \alpha$ subtype since $\mathrm{ER} \alpha$ is dominant in both breast epithelial cells and in breast cancer. However, we observed an oestrogen-induced activation of the promoter with ER $\beta$. We showed that the integrity of ER $\alpha$ is necessary to mediate the effects of oestrogens in the context of the hWISP2/CCN5 gene promoter. In fact, the results obtained favoured a predominant role for the AF-2-transactivating domain of $\mathrm{ER} \alpha$ although the presence of the transactivating domain AF-1 is necessary, as well as the DBD, to induce the activation of the hWISP-2/CCN5 gene promoter. This was not observed in the Xenopus laevis vitellogenin A2 ERETK-Luc context as HE19 mutant was an efficient inducible activator. The presence of the transactivating domain AF-1 may contribute to maintain a specific conformation of $\mathrm{ER} \alpha$ which is necessary for AF-2 to play its role in transactivating the hWISP-2/CCN5 gene promoter by oestrogens. This may be explained by favouring the selective recruitment of co-activators implicated in the oestrogen regulation of hWISP-2/CCN5 expression.

The presence of the DBD has also been determined as a requirement for the oestrogen-induced activation of the promoter suggesting that ER may interact directly with the hWISP-2/CCN5 gene promoter. The consensus ERE is $5^{\prime}$-GGTCANNNTGACC-3' based on the oestrogenresponsive sequence in the Xenopus laevis vitellogenin A2 promoter but only a fraction of the known mammalian oestrogen-responsive palindromic EREs reflects this consensus, instead consisting of variations on this sequence. This is the case for the ERE present in the hWISP-2/CCN5 gene promoter. The importance of the hWISP-2/CCN5 putative site as a functional ERE was established as follows: (i) deletion or mutation of this element abolished the oestrogenic response of the remaining hWISP-2/CCN5 gene promoter fragment; (ii) the oestrogen receptor association to this DNA 
element was demonstrated in vitro by using gel retardation assay and in vivo by using chromatin immunoprecipitation assay. The hWISP-2/CCN5 ERE sequence identified here resembles the human complement 3 ERE1 but the contribution of this sequence in the oestrogen upregulation of the human complement 3 and the way liganded ER interacts with it are different (Fan et al. 1996). We show that hWISP-2/CCN5 ERE is necessary and sufficient to confer oestrogen-induced activation to the hWISP-2/CCN5 gene promoter, contrary to human complement 3 ERE1, which is only part of the DNA elements required for maximal inducibility by oestrogens. Moreover, we show that ER $\alpha$ can interact with the hWISP-2/CCN5 ERE forming high affinity protein-DNA complexes, which is not the case for human complement 3 ERE1. These observations and our results contribute to reinforce the role of the oestrogen response element as an allosteric modulator of ER conformation, which can account for the specific regulation of oestrogen target gene expression (Wood et al. 1998, Gruber et al. 2004). Furthermore, the ERE motif identified here is conserved in the mouse WISP-2/CCN5 gene promoter region, located at about $300 \mathrm{bp}$ upstream from the first adenine residue of the translation initiation codon. This argues in favour of the biological relevance of the identified ERE sequence in the regulation of WISP-2/CCN5 expression by oestrogens. On other hand, the putative regulatory binding sites present in the promoter (AP-1, Sp-1, half EREs, TCF, NF(B, CRE) and others not yet identified could be implicated in the regulation of WISP-2/ CCN5 gene expression. This question needs to be further investigated in order to determine if they can participate at the modulation of $h W I S P-2 / C C N 5$ gene expression in human breast epithelial cells, as well as in other cellular contexts.

Recently, we demonstrated that $\mathrm{p} 21^{\mathrm{WAF} 1 / \mathrm{CIP} 1}$ selectively controls the transcriptional activity of $\mathrm{ER} \alpha$ in MCF-7 cells treated by oestrogens (Redeuilh et al. 2002, Fritah et al. 2005). The results of chromatin immunoprecipitation assays showed that endogenous $\mathrm{CBP}$ and $\mathrm{p} 21^{\mathrm{WAF} 1 / \mathrm{CIP} 1}$ are recruited concomitantly to ER $\alpha$ on the hWISP-2/CCN5 gene promoter in MCF-7 cells. The fact that CBP and p21 WAF1/ ${ }^{\mathrm{CIP} 1}$ participate at the ER $\alpha$-mediated transcriptional control of the hWISP-2/CCN5 and progesterone receptor genes in the same way reinforces the gene-specific action of $\mathrm{p} 21$ WAF1/ CIP1 attributed in its specific target gene promoter recruitment. In turn, since $\mathrm{p} 21^{\text {WAF1/CIP1 }}$ is involved in negatively regulating cell cycle progression by inducing growth arrest (Harper \& Elledge 1996), and supported by the fact that hWISP-2/CCN5 was demonstrated as being a growth arrestspecific gene in normal human vascular and uterine smooth muscle cells (Lake et al. 2003, Mason et al. 2004a), we can hypothesize that hWISP-2/CCN5 could function as a downstream effector of $\mathrm{p} 21^{\mathrm{WAF} 1 / \mathrm{CIP} 1}$ in human breast epithelial cells. Indeed, there is a significant correlation between p21 WAF1/CIP1 immunoreactivity and well-differentiated histological grade in ER $\alpha$-positive breast carcinoma (Oh et al. 2001). We showed that hWISP-2/CCN5 expression is induced by oestrogens in the T47D and ZR$75 \cdot 1$ cells contrary to the results obtained by Inadera et al. who observed no oestrogen-induced expression of hWISP-2/ CCN5 in either of these cell lines (Inadera et al. 2002). However, in line with our results showing that hWISP-2/ CCN5 expression is induced by oestrogens in ER-positive breast cancer cell lines, a significant correlation between hWISP-2/CCN5 and ER $\alpha$ positivity in human breast cancer samples has been established (Banerjee et al. 2003). In addition to oestrogen responsiveness of WISP-2/CCN5 in breast cancer tissue, it has recently been demonstrated that WISP-2/ CCN5 expression changes during the menstrual cycle and is positively regulated by oestrogens in the non-tumourigenic rat endometrium, endometrial glands and myometrium, in vivo (Mason et al. 2004b). This is analogous to the situation in the artery wall, in which endothelial and smooth muscle cells express WISP-2/CCN5 (Lake et al. 2003). It has also been shown that, while hWISP-2/CCN5 is expressed in the non-tumourigenic human myometrium it is deficient in leiomyomas suggesting that loss of WISP-2/CCN5 expression may account, at least, in part for tumourigenesis (Mason et al. 2004a). On the other hand, WISP-3/CCN6, which belongs to the WISP sub-family, was associated with tumour suppressor function in inflammatory breast cancer (Kleer et al. 2002). Collectively, these informations argue for a potential role of WISP-2/CCN5 in oestrogen-dependent tissue and particularly the implication of WISP-2/CCN5 in breast tumourigenesis needs to be further investigated.

\section{Acknowledgements}

We thank J Mester for the critical review of the manuscript. We thank D Catala for technical assistance. The authors declare that there is no conflict of interest that would prejudice the impartiality of this scientific work.

\section{Funding}

This work was supported by the Centre National de la Recherche Scientifique (CNRS) and by the Ligue Nationale contre le Cancer, comité de Paris. A F is the recipient of a doctoral fellowship from the Association pour la Recherche sur le Cancer. Sequence of the hWISP-2/CCN5 gene promoter was submitted to Genbank with Accession number DQ288855.

\section{References}

Banerjee S, Saxena N, Sengupta K, Tawfik O, Mayo MS \& Banerjee SK 2003 WISP-2 gene in human breast cancer: estrogen and progesterone inducible expression and regulation of tumor cell proliferation. Neoplasia 5 63-73.

Banerjee S, Sengupta K, Saxena NK, Dhar K \& Banerjee SK 2005 Epidermal growth factor induces WISP-2/CCN5 expression in estrogen receptoralpha-positive breast tumor cells through multiple molecular cross-talks. Molecular Cancer Research 3 151-162. 
Beato M, Herrlich P \& Schutz G 1995 Steroid hormone receptors: many actors in search of a plot. Cell $\mathbf{8 3} 851-857$.

Brigstock DR 1999 The connective tissue growth factor/cysteine-rich 61/ nephroblastoma overexpressed (CCN) family. Endocrine Reviews 20 189-206.

Brigstock DR 2003 The CCN family: a new stimulus package. Journal of Endocrinology 178 169-175.

Brigstock DR, Goldschmeding R, Katsube KI, Lam SC, Lau LF, Lyons K, Naus C, Perbal B, Riser B, Takigawa M et al. 2003 Proposal for a unified CCN nomenclature. Molecular Pathology 56 127-128.

Cavailles V, Dauvois S, L'Horset F, Lopez G, Hoare S, Kushner PJ \& Parker MG 1995 Nuclear factor RIP140 modulates transcriptional activation by the estrogen receptor. EMBO Journal 14 3741-3751.

Chen D, Riedl T, Washbrook E, Pace PE, Coombes RC, Egly JM \& Ali S 2000 Activation of estrogen receptor alpha by S118 phosphorylation involves a ligand-dependent interaction with TFIIH and participation of CDK7. Molecular Cell 6 127-137.

Chen D, Washbrook E, Sarwar N, Bates GJ, Pace PE, Thirunuvakkarasu V, Taylor J, Epstein RJ, Fuller-Pace FV, Egly JM et al. 2002 Phosphorylation of human estrogen receptor alpha at serine 118 by two distinct signal transduction pathways revealed by phosphorylation-specific antisera. Oncogene 21 4921-4931.

Delaunay F, Pettersson K, Tujague M \& Gustafsson JA 2000 Functional differences between the amino-terminal domains of estrogen receptors alpha and beta. Molecular Pharmacology 58 584-590.

Fan JD, Wagner BL \& McDonnell DP 1996 Identification of the sequences within the human complement 3 promoter required for estrogen responsiveness provides insight into the mechanism of tamoxifen mixed agonist activity. Molecular Endocrinology 10 1605-1616.

Fritah A, Saucier C, Mester J, Redeuilh G \& Sabbah M 2005 p21WAF1/CIP1 selectively controls the transcriptional activity of estrogen receptor alpha. Molecular and Cellular Biology 25 2419-2430.

Gronemeyer H 1991 Transcription activation by estrogen and progesterone receptors. Annual Review of Genetics 25 89-123.

Gruber CJ, Gruber DM, Gruber IM, Wieser F \& Huber JC 2004 Anatomy of the estrogen response element. Trends in Endocrinology and Metabolism 15 73-78.

Harper JW \& Elledge SJ 1996 Cdk inhibitors in development and cancer. Current Opinion in Genetics and Development 6 56-64.

Inadera H 2003 Estrogen-induced genes, WISP-2 and pS2, respond divergently to protein kinase pathway. Biochemical and Biophysical Research Communications 309 272-278.

Inadera H, Hashimoto S, Dong HY, Suzuki T, Nagai S, Yamashita T, Toyoda N \& Matsushima K 2000 WISP-2 as a novel estrogen-responsive gene in human breast cancer cells. Biochemical and Biophysical Research Communications 275 108-114.

Inadera H, Dong HY \& Matsushima K 2002 WISP-2 is a secreted protein and can be a marker of estrogen exposure in MCF-7 cells. Biochemical and Biophysical Research Communications 294 602-608.

Jacq X, Brou C, Lutz Y, Davidson I, Chambon P \& Tora L 1994 Human TAFII30 is present in a distinct TFIID complex and is required for transcriptional activation by the estrogen receptor. Cell 79 107-117.

Javahery R, Khachi A, Lo K, Zenzie-Gregory B \& Smale ST 1994 DNA sequence requirements for transcriptional initiator activity in mammalian cells. Molecular and Cellular Biology 14 116-127.

Kleer CG, Zhang Y, Pan Q, van Golen KL, Wu ZF, Livant D \& Merajver SD 2002 WISP3 is a novel tumor suppressor gene of inflammatory breast cancer. Oncogene 21 3172-3180.

Klock G, Strahle U \& Schutz G 1987 Oestrogen and glucocorticoid responsive elements are closely related but distinct. Nature 329 734-736.

Kumar V, Green S, Stack G, Berry M, Jin JR \& Chambon P 1987 Functional domains of the human estrogen receptor. Cell 51 941-951.

Lake AC, Bialik A, Walsh K \& Castellot JJ Jr 2003 CCN5 is a growth arrestspecific gene that regulates smooth muscle cell proliferation and motility. American Journal of Pathology 162 219-231.

Lo K \& Smale ST 1996 Generality of a functional initiator consensus sequence. Gene 182 13-22.

Mangelsdorf DJ, Thummel C, Beato M, Herrlich P, Schutz G, Umesono K, Blumberg B, Kastner P, Mark M, Chambon P et al. 1995 The nuclear receptor superfamily: the second decade. Cell $\mathbf{8 3} 835-839$.
Mason HR, Lake AC, Wubben JE, Nowak RA \& Castellot JJ Jr 2004a The growth arrest-specific gene CCN5 is deficient in human leiomyomas and inhibits the proliferation and motility of cultured human uterine smooth muscle cells. Molecular Human Reproduction 10 181-187.

Mason HR, Grove-Strawser D, Rubin BS, Nowak RA \& Castellot JJ Jr $2004 b$ Estrogen induces CCN5 expression in the rat uterus in vivo. Endocrinology 145 976-982.

Oh YL, Choi JS, Song SY, Ko YH, Han BK, Nam SJ \& Yang JH 2001 Expression of 21 Waf1, p27Kip1 and cyclin D1 proteins in breast ductal carcinoma in situ: relation with clinicopathologic characteristics and with p53 expression and estrogen receptor status. Pathology International 51 94-99.

O'Lone R, Frith MC, Karlsson EK \& Hansen U 2004 Genomic targets of nuclear estrogen receptors. Molecular Endocrinology 18 1859-1875.

Pennica D, Swanson TA, Welsh JW, Roy MA, Lawrence DA, Lee J, Brush J, Taneyhill LA, Deuel B, Lew M et al. 1998 WISP genes are members of the connective tissue growth factor family that are up-regulated in wnt-1transformed cells and aberrantly expressed in human colon tumors. PNAS 95 14717-14722.

Rachfal AW \& Brigstock DR 2005 Structural and functional properties of CCN proteins. Vitamins and Hormones 70 69-103.

Redeuilh G, Attia A, Mester J \& Sabbah M 2002 Transcriptional activation by the oestrogen receptor alpha is modulated through inhibition of cyclindependent kinases. Oncogene 21 5773-5782.

Reid G, Hubner MR, Metivier R, Brand H, Denger S, Manu D, Beaudouin J, Ellenberg J \& Gannon F 2003 Cyclic, proteasome-mediated turnover of unliganded and liganded ERalpha on responsive promoters is an integral feature of estrogen signaling. Molecular Cell 11 695-707.

Rosenfeld MG \& Glass CK 2001 Coregulator codes of transcriptional regulation by nuclear receptors. Journal of Biological Chemistry 276 36865-36868.

Sabbah M, Gouilleux F, Sola B, Redeuilh G \& Baulieu EE 1991 Structural differences between the hormone and antihormone estrogen receptor complexes bound to the hormone response element. PNAS 88 390-394.

Sabbah M, Radanyi C, Redeuilh G \& Baulieu EE 1996 The 90 kDa heatshock protein (hsp90) modulates the binding of the oestrogen receptor to its cognate DNA. Biochemical Journal 314 205-213.

Sabbah M, Kang KI, Tora L \& Redeuilh G 1998 Oestrogen receptor facilitates the formation of preinitiation complex assembly: involvement of the general transcription factor TFIIB. Biochemical Journal 336 639-646.

Shang Y, Hu X, DiRenzo J, Lazar MA \& Brown M 2000 Cofactor dynamics and sufficiency in estrogen receptor-regulated transcription. Cell 103 843-852.

Vandesompele J, De Preter K, Pattyn F, Poppe B, Van Roy N, De Paepe A \& Speleman F 2002 Accurate normalization of real-time quantitative RT-PCR data by geometric averaging of multiple internal control genes. Genome Biology 3 (RESEARCH0034).

Wood JR, Greene GL \& Nardulli AM 1998 Estrogen response elements function as allosteric modulators of estrogen receptor conformation. Molecular and Cellular Biology 18 1927-1934.

Wu SY, Thomas MC, Hou SY, Likhite V \& Chiang CM 1999 Isolation of mouse TFIID and functional characterization of TBP and TFIID in mediating estrogen receptor and chromatin transcription. Journal of Biological Chemistry 274 23480-23490.

Zhang R, Averboukh L, Zhu W, Zhang H, Jo H, Dempsey PJ, Coffey RJ, Pardee AB \& Liang P 1998 Identification of rCop-1, a new member of the CCN protein family, as a negative regulator for cell transformation. Molecular and Cellular Biology 18 6131-6141.

Zoubine MN, Banerjee S, Saxena NK, Campbell DR \& Banerjee SK 2001 WISP-2: a serum-inducible gene differentially expressed in human normal breast epithelial cells and in MCF-7 breast tumor cells. Biochemical and Biophysical Research Communications 282 421-425.

\section{Received in final form 11 September 2006 Accepted 20 September 2006 Made available online as an Accepted Preprint 2 October 2006}

